\title{
Theoretical Review of Effect of Firm Specific Factors on Performance of Initial Public Offering Stocks at the Nairobi Securities Exchange in Kenya
}

\author{
Anaclet Biket Okumu, Tobias Olweny, Willy Muturi \\ Jomo Kenyatta University of Agriculture and Technology, Nairobi, Kenya \\ Email: bokumu@mmarau.ac.ke, tolweny@jkuat.ac.ke,wmuturi@ihrd.jkuat.ac.ke
}

How to cite this paper: Okumu, A. B., Olweny, T., \& Muturi, W. (2021). Theoretical Review of Effect of Firm Specific Factors on Performance of Initial Public Offering Stocks at the Nairobi Securities Exchange in Kenya. Open Journal of Business and Management, 9, 327-352. https://doi.org/10.4236/ojbm.2021.91018

Received: November 24, 2020

Accepted: January 26, 2021

Published: January 29, 2021

Copyright $\odot 2021$ by author(s) and Scientific Research Publishing Inc. This work is licensed under the Creative Commons Attribution International License (CC BY 4.0).

http://creativecommons.org/licenses/by/4.0/ (c) (i) Open Access

\begin{abstract}
During the period 1994 to 2020, a total of 18 firms in Kenya floated 16,530,781,060 shares at the Nairobi Securities Exchange (NSE) under Initial Public Offerings (IPOs) raising over Kshs 91 billion. These stocks were significantly over-subscribed with the highest hitting $830 \%$. The NSE became fully automated in 2006. Similarly, in Africa between 2010 and 2019 there were a total of 215 IPOs raising over Kshs 1.6 trillion. This could be explained by divergence of opinion hypothesis. The initial returns were positive. However, in the long run, most of the firms underperformed. This under performance leads to losses incurred by investors and possible collapse of brokerage and investment firms leaving investors with a bitter taste. This study will undertake to establish the effects of firm specific factors on IPO stock performance at the NSE in Kenya. The specific objectives will be: to establish the effect of firm size on performance of IPO stocks at the NSE in Kenya, to determine the effect of age of firm on performance of IPO stocks at the NSE in Kenya, to evaluate the effect of firm board composition on performance of IPO stocks at the NSE in Kenya, to establish the effect of firm ownership structure on performance of IPO stocks at the NSE in Kenya, and to analyze the moderating effect of automation on the firm specific factors and performance of IPO stocks at the NSE in Kenya. The study will be built upon major theoretical streams: Random Walk theory, Winners curse theory, Dow Theory, Signaling theory and Agency theory and contextualize them to firm specific factors and performance of IPO stocks. More studies have previously been undertaken on the pricing of IPO at the NSE in Kenya and the few that studied on performance of IPO stocks at the NSE in Kenya have provided mixed findings depending on the methodology used. None of the studies as
\end{abstract}


far as research has shown have considered the automation of NSE in Kenya as a moderating effect of performance of IPO stocks. The sample size will be the same as population of 18 IPO firms between 1994 and 2020 with 8 IPOs during pre-automation and 10 IPOs post-automation period. This will be a longitudinal and event study that will adopt a descriptive study design. Data will be analyzed using the Econometric Views (Eviews). Hausman test, Augmented Dickey Fuller (ADF) test and other diagnostic tests will be applied to the panel data. The Capital Assets Pricing Model (CAPM) and the Nairobi 20 Share Index will be used as the benchmarks of performance of IPO stocks.

\section{Keywords}

Initial Public Offerings (IPOs), Performance, Automation, Firm Specific Factors, Nairobi Securities Exchange

\section{Introduction}

\subsection{Background of the Study}

A stock exchange is established to maintain active trading which increases the liquidity or marketability of shares, help fix share prices that arise through transactions that flow from investors demands and suppliers preferences, ensure safe and fair dealing through rules, regulations and by-laws established, aid in financing the economy through negotiability and transferability of the securities, dissemination of information through various publications, and lastly act as a performance inducer since prices of stocks reflect the performance of traded companies (Joshi, Sabhaya, \& Pandya, 2013).

The financial reform process emphasizes the development of the securities market as an alternative source of long-term capital in emerging market which is crucial for economic development given the positive relationship between long-term capital and economic growth (Obura \& Anyango, 2016). As a priority therefore, the Kenya government in the 1997/2001 Development Plan noted the need to shift from the more expensive short-term finance in favor of cheaper long-term finance for sustainable industrialization to be achieved. The long term finance can be achieved through IPO listing which is a method of raising funds through the issue of shares to investors in a primary market by companies (Joshi et al., 2013). Initial public offerings (IPOs) can be observed as a process consisting of two essential parts. The first one can be observed as the initial public offering of a company's common shares, while the second one can be observed as the listing of a company's share on a stock exchange (Karanovic \& Karanovic, 2016). In order to gain greater liquidity and better access to capital, companies sell their equity to the public through Initial Public Offerings (IPOs) and Secondary Equity Offerings (Simiyu, Mutunga, Barasa, \& Matete, 2016). Madura 
(2010) states that equity markets facilitate the flow of funds from individual or institutional investors to corporations and enable the corporations to finance their investment in new or expanded business ventures. The overriding motivation for an IPO is to establish a liquid market for the firm's stock (Zheng, Ogden, \& Jen, 2002). IPOs tend to occur during bullish stock markets when potential investors are more interested in purchasing new stocks.

Through the IPO process, new companies in the capital markets make the public issue for the first time. Such issues are floated through prospectuses, book building, private placements, bought out deals and rights issues. Brigham and Ehrhardt (2011) define an IPO as the first selling of company's stock to outside investors and then letting the stock trade in securities' markets. IPOs offer opportunities for firms to diversify ownership, use stock markets as an exit strategy for mature businesses and raise funds for investment (Marc, Khurshed, \& $\mathrm{Mu}$ dambi, 2007 as cited in Osei, Adjasi, \& Fiawoyife, 2012). A person offers securities to the public in Kenya if, to the extent that the offer is made to persons in Kenya, it is made to any section of the public, whether selected as members or debenture holders of a body corporate, or as clients of the person making the offer, or in any other manner, is to be regarded as made to the public; and the terms "public offer" and "public offering" shall be construed accordingly (Government of Kenya, 2002). Mburugu (2016) stated that an entity that desires to initiate an IPO in Kenya has to first obtain the authorization from Capital Markets Authority (CMA) before it can carry out an IPO.

\subsection{Global Perspective of Performance of IPO Stocks}

The issue of public offerings has resulted in real liquidity creation by the issuing firms globally and this is why its study is of importance to academicians, policy makers and industry players in equal measure. Firms have been able to raise significant amount of equity and debt finance through IPOs. For instance, between 1980 and 2001, the number of companies going public in the United States exceeded one per business day raising US $\$ 488$ billion in gross proceeds (Ritter \& Welch, 2002). Specifically, in 2010 the Global IPO volume was US\$ 280 billion with Asian Pacific accounting for 45\% (Philippe, 2012). In India, the IPO market witnessed an exploding growth from 158 issues during 1991-1992 amounting to Rs. 724 crores to 1357 IPOs for Rs. 10,924.11 crores during 1995-1996 (Chhabra, 2011). Globally during the first half of 2015, there were 631 IPO deals raising US\$ 103.7 billion distributed as 123 deals in financial sector, 119 deals in industrial sector, 97 deals in health care and 94 deals in technology (Ernest and Young Global IPO Trends, 2015).

In Malaysia, on average, the IPOs from the private sector are underpriced and show a pattern of underperformance (negative returns) in the long-run up to five years. The initial excess returns are caused by the percentage of share sold, the uncertainty about the future value of the firm, the market index fluctuation, the size of firm and the value of issue on the first day of trading (Isnurhadi, Umar, 
Diah, \& Herianto, 2008). In China, on the other hand, the average underpricing of IPOs is severe with $40.4 \%$ in 2010. In the United States of America, there has been modest IPO underpricing. These IPOs have also underperformed for instance out of 7314 U.S. IPOs from 1980-2008, the average 3-year buy-and-hold return from the first closing market price was $20.8 \%$ (Ritter, 2011). Lee, Taylor and Walter (1996) found IPOs in Australian markets from 1976-1989 underperformed a control group by $51 \%$ in three years while Ljungqvist (1997) found that IPOs in German markets from 1970-1990 underperformed control group by $12 \%$ in 3 years.

In the Hong Kong stock market, IPO's covering the years 1993-1997, there is a strong relationship between investor demand for IPO's and the short and long-run post-issue performance of IPO's whereby the Investor demand for IPO's is positively related to the initial returns of these firms. The returns of the first trading day indicate that the IPO's with high investor demand is significantly underpriced while the IPO's with low investor demand are overpriced (Agarwal, Liu, $\&$ Rhee, 2008). The long-run size-adjusted excess returns of IPO's are negatively related to investors demand. IPO's with high investor demand have large positive initial returns but negative longer-run excess returns while IPO's with low investor demand have negative initial returns but positive longer-run excess returns. Investors' demand for an IPO is largely driven by investor's overreaction to the information about the prospects prior to the offerings.

In Canada, investors experienced loss in the long run IPO performance of five years (Kooli \& Suret, 2004). In the UK on the other hand, small companies behaved differently from large companies and suffered from worse long run performance than large companies (Marc, Khurshed, \& Mudambi, 2006). Interestingly in Spain capital market, Alvarez and Gonzalez (2001) found that the long run underperformance is nonexistent.

The Jordanian initial public offerings (IPOs) listed in Amman stock exchange during the period from (1st January, 1993 until 31st December, 2011) comprising of 119 companies and monthly returns of 60 months shows that the IPOs underperform in the long run although the level of underperformance differs with the kind of benchmark that is employed to measure the long run performance (Fawaz \& Osama, 2015). In the UK, using a sample of 712 IPOs from 1980 to 1988 Levis (1993) found that the long run performance is based on three alternative benchmarks: the financial time actuaries all share index (FTAI), the Hoar Govett small companies index (HGSCI), and all share equally weighted index (ASEWI).

\subsection{Performance of IPO Stocks in Africa}

In Africa, there were 28 IPOs raising US\$ 2.9 billion in 2017 while between 2013 and 2017 there were a total of 134 IPOs raising US\$ 9.1 billion (Africa Capital Markets Watch, 2019). In 2017, Namibia showed renewed IPO activity with the \$13.5-million listing of Letshego Holdings (Namibia) Ltd. Overall African equity 
capital markets transaction volume and value improved in 2017 over 2016. In terms of value, 2017 saw the largest IPO over the trailing five-year period, and an increase in the total value of equity capital markets transactions of $49 \%$ between 2016 and 2017 in US dollar terms.

During the period 1990-2009, the Ghanaian stock market on average were under-priced on initial trading day by $8.43 \%$. Age, cost of debt, hot market, leverage and industry were the main determinants of under-pricing (Esumanba, Kpanie, \& Bernard, 2015). In Tunisia, investors rely on other indicators of firm IPO performance rather than firm's characteristics as disclosed in the IPO prospectus. Therefore, age, size of the firm and offer size do not have any impact on the level of underperformance. These factors do not seem to reduce the amount of money left on the table by issuers (Sarra, Adbelkader, \& Neila, 2011). However, in Mauritius, information disclosed in the prospectus such as cash flows and sales are positively related to the level of initial underpricing (Gasbarro, Bundoo, \& Zumwalt, 2003).

The South African IPOs on the JSE are underpriced with average market-adjusted returns of $78.10 \%, 78.57 \%$ and $82.81 \%$ for the first day, first week and first month respectively. Over three years' period, they underperform using the market model of $-65.59 \%$ and $-59.77 \%$, for BHAR and CAR respectively (Neneh, 2013). Munisi (2017) examined the difference in financial performance before and after Initial Public Offerings (IPOs) in companies listed on Dar es Salaam Stock Exchange (DSE) in Tanzania whereby the company financial performance was measured using financial performance ratios revealed that there is significant difference between pre-IPOs and post-IPOs financial performance with significant increase of post-IPOs financial performance. The study indicated that there was no significant evidence that pre-IPOs performance was higher than post-IPOs performance.

Hearn (2011) investigated the impact of board governance features and the presence of foreign, indigenous high society executives and board diversity on levels of IPO underpricing in a unique sample of 62 Initial Primary Offerings (IPOs) from across Sub Saharan African (SSA), excluding South Africa. It was found that greater numbers of foreign executives increase underpricing while higher numbers of indigenous high society directors have an opposing effect. Increasing board ethnic and nationality diversity together with the establishment of nominally independent board monitoring and oversight committees were associated with higher underpricing implying that standard international governance best practice is inappropriate in a developing region dominated by narrow political economies underscored by underdeveloped formal institutions with minimal investor protection.

The initial and after-market short-run and long-run IPO returns on the Ghanaian and Nigerian stock markets over the period 1990 to 2006 show that the Ghanaian IPOs, on average, are underpriced on the initial trading day by $6.7 \%$ (market unadjusted) and $6.2 \%$ (market adjusted). In the case of Nigeria, the av- 
erage underpricing is much higher at $43.3 \%$ and $43.1 \%$ for market unadjusted and market adjusted abnormal returns, respectively (Osei, Adjasi, \& Fiawoyife, 2012). There is evidence of three-year long-run underperformance as evidenced by low mean buy and hold average return (BHAR) of $1.5 \%$ for the IPOs in Ghana and $0.6 \%$ for IPOs in Nigeria. The initial abnormal returns for the IPOs of Nigeria show that size of firm and audit quality are important variables affecting underpricing.

Using a sample of 34 Tunisian IPO's from the period 1992-2008, it was established that an average market adjusted initial return for the first three trading days was 17.8 percent (Zouari, Boudriga, \& Taktak, 2011). The factors significantly related to the underpricing were retained capital, underwriter's price support, oversubscription, listing delay and the offer price. Age of the firm, its size and the size of the offer did not seem to reduce the amount of money left on the table by issuers. It appeared also that underpricing was driven by irrational investors seeking for short-run capital gains. These results remain unchanged after controlling for the presence of institutional investors, price discount and the existence of liquidity contract. Overall, the results show that investors rely mainly on side information to value IPOs.

Achua (2011) explored the impact of the rapid regulatory changes in emerging African capital markets on initial public offerings (IPO). Employing equally-weighted average, equity IPO was underpriced by 4.9 percent; and regression analysis showed that IPO volumes, offer size, the age of the firm before IPO, issuers prospects and underwriters reputation were not robust IPO returns determinants, unlike market conditions and syndicate underwriting. This study confirmed decreasing IPO underpricing and identified changing dynamics of initial returns determinants in response to regulatory refinements in Nigeria.

\subsection{Performance of IPO Stocks in Kenya}

In Kenya, there are mixed results as regards under performance. Using Buy and Hold Abnormal Returns between 2000 and 2006, Wamari (2014) established growth in BHAR of the following firms: Kenya Reinsurance from 2.45 to 8.16, Access Kenya from 1.29 to 2.18, Equity bank from 1.43 to 4.87 while Scan group and Mumias Sugar dropped from 3.02 to 1.73 and 8.61 to 2.65 respectively. Using Cumulative Abnormal Returns (CAR) between 2006 and 2011, Mwendwa (2014) found that the following firm's performance experienced no or insignificant change in returns: Scan group remained at $1.608 \%$, Access Kenya from $1.78 \%$ to $1.73 \%$, Kenya Reinsurance from $-0.512 \%$ to $-0.520 \%$ while Safaricom and Co-operative bank outperformed the market from $-0.954 \%$ to $1.59 \%$ and $0.284 \%$ to $0.783 \%$.

Kanja (2014) established that initial public offerings affect stock returns of companies listed at the NSE. This was when a review was done on the effects of initial public offerings on performance of stocks of companies quoted at NSE between 2006 and 2013. All the 62 listed companies at the NSE were studied. 
The study found that the median return was lower than the (equal weighted) average return suggesting that the distribution of initial returns was skewed to the right, as expected. Over the entire sample, the equal-weighted average initial return exceeded the value weighted average by a factor of 1.75 , which suggested that IPO offer was an important determinant of initial return.

At the NSE, stock under performs in the long run after IPO but not significantly. This finding was made by (Wamari, 2014). Variables that show the performance of the stock in the long run such as share price, earnings per share and price earnings ratio of the stock were analyzed on seven companies which went public between 2000 and 2006 using the Buy and Hold Abnormal Returns (BHAR) model. Hypothesis testing was done using the student's t-test at 95\% confidence level to find whether there is significant under performance of IPOs in the long run. The trend analysis findings showed that share price, price earnings ratio and the overall stock performance decreased in the long run after IPO. However, the earnings per share increased after IPO. The buy and hold abnormal returns decreased in the long run after IPO; however, the test of significance findings at $5 \%$ level of significance showed that the decrease in stock performance after IPO was not significant.

Variation in long run performance of shares at NSE was explained jointly by 1st Day pricing differential between the offer price and closing day one price (Simiyu, Mutunga, Barasa, \& Matete, 2016). All firms that issued IPO at NSE from 2000-2013 were studied and analyzed using descriptive statistics. Age in years of firm was the difference the between the offer firm's IPO year and the founding year, size of the firm as measured by total assets, number of shares issued and the percentage subscription as the obtained coefficient of determination $\left(\mathrm{R}^{2}\right)$. The study revealed that the regression model predicting the relationship between the long run performance of shares and independent variables was significant. The study deduced that holding all the other factors constant, long run performance of shares would be 8.736 .

Profitability, asset base and sales volume turnover play a small role in influencing the performance of initial public offering at the Nairobi Securities Exchange (Mushtag, 2016). From the study it was found that there was evidence of a positive relationship between asset base and IPO performance with a correlation value of 0.299 , while a correlation value of sales volume turnover and IPO performance yielded a value of 0.213 and between profitability and IPO success had a correlation value of 0.097 . 6.5\% of the variation in IPO performance was explained by profitability, asset base and sales volume turnover while $93.5 \%$ constituted of other factors Holding all the other factors constant, a unit increase in asset base leads to an increase in IPO performance, a unit increase in sales volume turnover would lead to an increase in IPO performance and a unit increase in profitability would lead to a decrease in IPO performance.

All types of ownerships structures have a significant positive influence on the firm's financial performance in Kenya (Ng'ang'a, 2017). Foreign ownership and 
Managerial shareholding have the highest positive significant contribution on firm's performance. This can be attributed to the fact that foreign owners have the ability to control and monitor managers. For managerial shareholding, it's backed by the fact that managers work better in an environment where they are afforded an opportunity to own shares of the firm, have freehand to exercise their professional judgment without undue influence from shareholders. For local ownership better understanding of local environment enhances performance while government ownership boosts confidence among investors.

Gatumo (2017) established that offer price, offer size, subscription rate, turnover, net assets, age, market return and market volatility were not statistically significant in explaining the performance of initial public offering in Kenya. This was found when a study of the factors that impact the performance of initial public offering in the short run was carried out in Kenya. The population for the study comprised of all the firms listed between 2000 and 2014 in Nairobi Securities Exchange.

Chibeka (2014) found that $51.5 \%$ of the variation in long run performance of shares was explained jointly by 1st Day pricing differential between the offer price and closing day one price. The regression model predicting the relationship between the long run performance of shares and independent variables were significant. Long run performance of shares would be 8.736. A unit change which is the difference between offer price and closing day one price led to change in long run performance of shares by 0.068 . Firm age, size of the firm, number of shares issued, and percentage had minimal effects on long run performance of shares.

Mutai (2018) established that firm characteristics affect the performance of a company at the Nairobi Securities Exchange, with underpricing being more significant in newer (riskier) firms (rho $=-0.58, p<0.05$ ) while bigger firms experienced less CAR compared to smaller firms (rho $=-0.37, p<0.05$ ). He also found that higher post-IPO Return on Equity in companies owned by institutions rather than by individuals (rho $=0.41, P<0.05$ ) and those in finance (rho $=0.41, p<0.05)$ compared to those in industrial and allied sector.

In Kenya, 10 firms went public between 2006 and 2020 with 13.1 billion shares raising over Kshs 75 billion (Capital Markets Authority, 2020). This study is not directly concerned in understanding and explaining long-term underperformance. Instead the study shall measure firm characteristics at the time of IPO that are associated with long-term performance in a methodical way. These characteristics are based on theoretical considerations, previous research on IPOs and general theory of the firm. The long-run performance of the IPOs is hypothesized to be a function of the managerial decisions and performance of the firm after going public (Fawaz \& Osama, 2015). To test this proposition a number of characteristics of the firms are used: size of the firms, age of firms, firm's board composition, firm's ownership and automation of NSE.

This research shall complement the previous studies to see if there is an effect 
of the firm's characteristics on IPO stock performance in the long term for the IPO firms listed in the Nairobi Securities Exchange. Quantitative study design using panel data and event study approach shall be employed to measure the performance of IPO stocks in the long-term during the period 1994 to 2020 using the Nairobi Securities Exchange All Share Index. The research will seek to answer several questions like; if the IPO stock performance is sensitive to the benchmark employed and is affected by firm specific factors.

Buy and Hold Abnormal returns (BHAR) and Cumulative Abnormal Returns (CAR) will be used to measure the performance of the stocks. Barber and Lyon (1997), Lyon, Barber and Tsai (1999) and Kothari and Warner (1997) have examined several long-run stock market performance measures and their common finding was that no single performance measure is dominant. However, some researchers (Fama, 1998; Gompers \& Lerner, 2003; Mitchell \& Stafford, 2000) have argued that the CAR is a better and less biased performance measure for evaluating long-run performance. Specific benchmarks to be applied to the actual IPO stock performance are Capital Asset Pricing Model (CAPM), the Nairobi All Share Index (NASI) and matching firm's performance.

\section{Statement of the Problem}

Initial Public Offerings have resulted in real liquidity creation by the issuing firms globally and this is why its study is of importance to academicians, policy makers and industry players in equal measure. During the 1994 to 2020 the IPO stocks at NSE were significantly over-subscribed with the highest hitting $830 \%$. In Africa, there were 9 IPOs raising US\$ 1.2 billion in 2019 while between 2010 and 2019 there were a total of 215 IPOs raising US\$ 16.9 billion (Africa Capital Markets Watch, 2019). The high amount of income raised from IPOs is a testament of investor confidence and appetite for IPO market. This could be explained by divergence of opinion hypothesis proposed by Miller and Reilly (1987) as cited by (Yaakub, Sherif, \& Haniffa, 2018). Despite the oversubscription, evidence from first day trading shows significant IPOs underpricing. Globally, the positive initial return ranged from $3.30 \%$ in Russia to $270.10 \%$ in United Arab Emirates during the period 1959 to 2019 (Loughran, Ritter, \& Rydqvist, 2020). In Kenya, the first day trading for IPOs floated between 1997 and 2008 at the NSE had a mean underpricing of 55.36\% (Mutai, 2019). Within a two-year period, the Cumulative Abnormal Returns (CARs) test had a negative of -1.18403 for IPOs between 2001 and 2008 (Koech, 2011).

Performance of IPO stocks is a combination of both price and returns. Previous studies on performance of IPO stocks at the NSE include: Simiyu, Mutunga, Barasa and Matete (2016) established that $51.5 \%$ of the variation in long-run performance of shares was explained jointly by 1st day pricing differential between the offer price and closing day one price; Kiluku (2014) found positive relationship between IPO price and the first day price with a significance level of underpricing; Mwendwa (2014) established that the results of IPO performance 
differed from one methodology to the other; Wamari (2014) found that share price, price earnings ratio and the overall stock performance decreased in the long run after IPO and the earnings per share increased after IPO; Kinyua, Nyanumba, Gathaiya and Kithitu (2014) revealed a positive relationship between IPO and firm performance and Omuchesi and Bosire (2014) established that the introduction of the ATS had no statistically significant effect on market efficiency.

According to Loughran and Ritter (2002) determinants of IPO performance vary from firm's specific factors such as profitability, size, and industry, market condition, to investor behaviors. Whereas measurement of the former can be definite, it is complex to measure investor behavior. Guided by this premise, this study undertakes to establish the effects of firm specific factors on IPO stock performance. Previous studies in Kenya have explored IPO stock performance and pricing and none has addressed the effect of firm specific factors on IPO stock performance with moderating effect of automation of NSE (as far as the researcher was able to establish from a review of available previous studies) yet this could provide a solution IPO stock performance. This study shall attempt to fill this knowledge gap.

\section{Objectives of the Study}

\subsection{General Objective}

To establish the effect of firm specific factors on performance of IPO stocks at the Nairobi Securities Exchange in Kenya.

\subsection{Specific Objectives}

The study will be carried to achieve the following specific objectives:

1) To establish the effect of firm size on performance of IPO stocks at the Nairobi Securities Exchange in Kenya.

2) To determine the effect of age of firm on performance of IPO stocks at the Nairobi Securities Exchange in Kenya.

3) To find out the effect of firm board composition on performance of IPO stocks at the Nairobi Securities Exchange in Kenya.

4) To establish the effect of firm ownership structure on performance of IPO stocks at the Nairobi Securities Exchange in Kenya.

5) To determine the moderating effect of automation on the relationship between firm specific factors and performance of IPO stocks at the Nairobi Securities Exchange in Kenya.

\section{Research Hypotheses}

The study will be carried out to test the following null hypothesis:

$H_{01}$ : Firm size has no significant effect on performance of IPO stocks listed at the Nairobi Securities Exchange in Kenya.

$H_{02}$ : Age of the firm has no significant effect on performance of IPO stocks 
listed at the Nairobi Securities Exchange in Kenya.

$H_{03}$ : Firm board composition has no significant effect on performance of IPO stocks listed at the Nairobi Securities Exchange in Kenya.

$H_{04}$ : Firm ownership structure has no significant effect on performance of IPO stocks listed at the Nairobi Securities Exchange in Kenya.

$H_{05}$ : Automation has no significant moderating effect on the relationship between firm specific factors and performance of IPO stocks listed at the Nairobi Securities Exchange in Kenya.

\section{Theoretical Review}

The study shall be hinged on the following theories: Random walk theory, winner's curse theory, Dow Theory, signaling theory and agency theory.

\subsection{Random Walk Theory}

The term was first considered by Jules Regnault in his book entitled "Calcul des Chances et Philosophie de la Bourse", published in 1863. Afterwards, this theory was restated by Louis Bachelier in his Ph.D. paper from 1900, "Théorie de la speculation". Until early 1930s, the theory of random walk was ignored by researchers and scientists. Between 1930 and 1940, there were a few articles prepared on this subject, one of them by Alfred Cowles who concluded that investors do not manage, on average, to obtain abnormal returns as compared to market. Fama (1965) studied random walk theory in late 1960s and early 1970s, after he finished his Ph.D. paper. Specifically, in his Doctoral dissertation titled: "The behavior of Stock-Market Prices", published in the Journal of Business in January, 1965 where it discussed the theory of random walks in substantial detail providing extensive empirical evidence to support the theory. This paper was delivered as a talk at the 1965 Management Conference of the Graduate School of Business and the Executive Program Club.

Random walk hypothesis depicts weak form of market efficiency and states that successive price changes in individual securities are independent random variables. According to Fama (1965) and Kendall (1953), stock prices fluctuate randomly around their intrinsic values and return quickly towards the equilibrium and fully reflect the latest information available in the market. The random walk is unbiased thus sometimes the market will over-adjust and other times it will under-adjust, but it cannot be predicted which one will occur at any given time.

The idea of stock prices following a random walk is connected to that of the Efficient Market Hypothesis. The premise is that investors react instantaneously to any informational advantages they have thereby eliminating profit opportunities. Thus, prices always fully reflect the information available and no profit can be made from information based trading (Lo \& MacKinley, 1999). Cuthbertson and Nitzsche (2004) define a random walk with a drift $(\delta)$ as an individual stochastic series. 
There are three main factors that affect a stock's return: the return on the market portfolio less the risk-free rate of interest, the difference between the return on small and large firm stocks and the difference between the return on stocks with high book-to-market ratios and stocks with low book-to-market ratios (Brealey, Myers, \& Allen, 2005). LeRoy (1989) and Elton, Gruber, Brown and Goetzmann (2002) put forth a more flexible model called the "martingale". This improved on the random walk model as it can be generated within a reasonably broad class of optimizing models. It is a stochastic model whereby given the information set there is no way an investor can use it to profit beyond the level which is consistent with the risk inherent in the security. The martingale is superior to the random walk because stock prices are known to go through periods of high and low turbulence, a behavior that could be represented by a model in which successive conditional variances of stock prices but not their successive levels are positively auto-correlated.

This theory presumes that information is freely and readily available. Because of competition, new information on intrinsic values is reflected instantaneously in the actual prices making all non-random fluctuations so small that they cannot be exploited profitably. The security prices reflect all information that is publicly available (Bodie, Kane, \& Marcus, 2009). It is the action of information coming in a random, independent, unpredictable fashion with numerous competing investors adjusting stock prices rapidly to reflect this new information that makes the price changes $s$ to be independent and random.

However two arguments against random walk are based on market over-under reaction that was presented by Hirshleifer (2001) who discussed conservatism and argued that under appropriate circumstances individuals do not change their beliefs as much as would a rational Bayesian in the face of new evidence while Bouman and Jacobsen (2002) found evidence of lower market returns in the months between May and October compared with the rest of the year bringing about the effect of seasonal trends instead of random walk. Lagoarde-Segot and Lucey (2008) claimed that an informationally efficient stock market is essential for the positive relationship between developed stock markets activities and economic growth. On the other hand, an inefficient market can result in profitable investment opportunities based upon technical trading strategies.

The relevance of this theory to long run IPO performance is amplified by various studies which analyzed the efficiency of capital markets. In their articles, Mitchell \& Stafford (2000), Loughran and Ritter (1995), Spiess and Affleck (1995) and Levis (1993) proved that, after an IPO, stock prices tend to increase reaching a level to high compared to their normal level and their adjustment gradually reaches the average level. Dharan and Ikenberry (1995) on the other hand concluded that the stock price reduction on long run after finalization of the IPO is caused by investors' over-reaction at the moment of the events' announcement. Hence the random walk theory studies are associated with both under performance and over performance of IPO stocks. 


\subsection{Winner's Curse Theory}

The term "Winner's Curse" was first coined by Capen, Clapp \& Campbell in their 1971 paper "Competitive Bidding in High Risk Situations". These three were petroleum engineers who claimed that oil companies had suffered unexpectedly low rates of return in the 1960's and 1970's. They argued that these low rates of return resulted from the fact that winning bidders ignored the informational consequences of winning and naively based their bids on the unconditional expected value of the item which, although correct on average, ignored the fact that you only win when your estimate happens to be the highest (or one of the highest) of those competing for the item. But winning against a number of rivals following similar bidding strategies implies that your estimate is an overestimate of the value of the lease conditional on the event of winning thus producing below normal or even negative profits. The systematic failure to account for this adverse selection effect is commonly referred to as the winner's curse: you win, you lose money, and you curse.

Bazerman and Samuelson (1983) conducted the first experiment demonstrating a winner's Curse using M.B.A. students at Boston University. The experiment was conducted in class, with students participating in four first-price sealed-bid auctions whereby the bidders formed their own estimates of the value of each of four commodities. Cox and Isaac (1984) argued that the winner's curse cannot occur if all the bidders are rational and hence evidence of a winner's curse in the market settings would constitute an anomaly. As a result, investors will only buy shares if the IPOs are underpriced sufficiently to compensate them for the risk.

Rock (1986) applied the concept of the winner's curse to the new-issue market. He categorized investors into two types; informed and uninformed whereby informed investors are knowledgeable about the future prospects of the shares being sold and will only attempt to buy when the issue is underpriced. Contrary, uninformed investors do not know which issues are underpriced or overpriced, and therefore do not discriminate between issues when they apply for IPOs. Thus they are only able to get a small fraction or none at all if the demand for new shares is high. This information asymmetry may lead to a "lemons problem," where the uninformed investors end up primarily with the less successful IPOs. Keeping them in the market, therefore, requires an additional premium-the average underpricing of all IPOs. The concept of winner's curse to the new-issue market was extended by Beatty and Ritter (1986). In this model, uninformed investors most often bid successfully for overpriced new issues, since informed investors crowd them out of underpriced new issues. If new issues were not, on average, underpriced, uninformed investors would realize negative returns and withdraw from the new-issue market.

Varaiya (1988) defines winners curse as a situation in a biding situation where a party which unknowingly overestimates the value of a given object tends to bid higher than its competitors and is therefore more likely to win. It is the differ- 
ence between bid premium of winning bidder and the maximum offerable premium conditional on the capital markets estimates of expected takeover gains.

Ritter (1998) explains the Winner's curse from the perspective of informed and uninformed traders in connection with underpricing. If demand for shares is high, there shall be rationing since a fixed number of shares are normally offered to the market. Since some investors are at informational disadvantage relative to others, some investors will be worse off and if some investors are more likely to attempt to buy shares when an issue is underpriced, then the amount of excess demand will be higher when there is more underpricing. The winner's curse occurs with regard to uninformed traders whereby if they get all of the shares which they ask for, it is because the informed investors don't want the shares. Therefore, they will only raise requisitions if IPOs are underpriced sufficiently to compensate them for the bias in the allocation of new issues.

Bereby-Meyer and Grosskopf (2008) introduced a variation of winner's curse in which the participants were given an option to not bid, as there was a concern that participants otherwise bid positive amounts simply because they assume that they are supposed to do so; the median bid was 35 . In another condition, they reduced the payoff variability by requiring participants to submit a bid that applies to each of 10 firms. Feedback was given about the average profit made; in one condition the value of each of the firms and the profit from each individual outcome was also reported which led to some success in reducing the winners curse.

Eyster and Rabin (2005) introduced the concept of the Cursed Equilibrium which provided an elegant formalization of the psychological principle that one tends to under-appreciate the cognition processes and/or the informational content of others. They defined and applied this notion to variety of economic environments ranging from common-value auctions, Akerlof's lemon market, the take-over game, and voting in juries. Their cursed equilibrium is an attempt to address the overwhelming evidence, coming in particular from experimental data, that game-theoretic predictions based on common-knowledge and fully rational decision-makers often miss the mark completely.

Markets where investors know a priori that they do not have to compete with informed investors, IPOs are not underpriced. Therefore, the relevancy of this theory to IPO performance is under pinned to the fact of underpricing of IPOs as a competitive outcome of informed and uninformed investors. The information imperfection can affect firm specific factors such as board composition and firm ownership structure in decision making leading to IPO under performance.

\subsection{Dow Theory}

Charles Dow first created and indexed similar stocks-the industrials and railroads in 1897. The term "Dow Theory" emerges to have first been used in a 1902 book by Samuel Armstrong Nelson entitled "The ABC of stock speculation". Charles Dow was one of the founders of Dow Jones \& Co. (DJ, NYSE), publisher of The Wall Street Journal. The Dow Theory was developed by Charles 
Dow from his analysis of market price action in the late 19th century and refined by William Hamilton and S.A. Nelson after his death in 1922. In 1932 Robert Rhea further refined the analysis. Rhea studied and deciphered some 252 editorials through which Dow and Hamilton conveyed their thoughts on the market.

The Theory is based on the changes in price of the stocks which are bought and sold every business day. Each share of stock represents ownership of a definite fraction of some business enterprise. The owner of each share of stock is virtually a partner in that business. The theory is based on two assumptions: manipulation of the primary trend is not possible and averages discount everything. The markets reflect all known information therefore everything there to know is already reflected in the markets through price. In a case of unexpected outcomes, this will only affect the short-term trend leaving the primary trend. Even if sometimes the market can react negatively to good news the markets look ahead whereby the investor buys on the rumor and sell on the news. However, Ross (2012) argues that these assumptions do not apply in the current situation where movement of goods and services has transformed with many rail, air and road transport.

Dow theory is grounded on six tenets: averages discount everything-every single factor that influences demand and supply is in the market price, the market has three trends-primary, secondary and minor trends, major trends has three phases-accumulation, public participation and distribution phase, averages must confirm with each other-for a valid change of trend industrial and rail averages must confirm each other, volume must confirm with the trendpaid more attention to price and volume was only taken as secondary indicator and lastly a trend is assumed to be in effect until it gives definite signals that it has been reversed-trends keep on existing despite of the market noise.

The relevancy of Dow Theory to IPO performance is based on the fact that it stands upon the philosophy that the market prices reflect every significant factor that affects supply and demand (technical analysis). These essentially include the firm specific factors under this study and also includes volume of trade, fluctuations in exchange rates, commodity prices and bank rates. Therefore, the daily closing price reflects the psychology of all players involved in a particular marketplace or the combined judgment of all market participants. It is the target of the theory to find out changes in the major trends or movements of the market that indeed points to the IPO performance. Secondly, Dow Theory basic assumptions are used by chartists in their technical analysis to this day. The theory focused on price movements and index trends whose implementation can also incorporate elements of fundamental analysis.

\subsection{Signaling Theory}

Signaling theory describes behavior when two parties have access to different information. When this happens, one party, the sender, must choose whether 
and how to communicate (or signal) that information, and the other party, the receiver, must choose how to interpret the signal. Signaling theory is applied in a variety of management literatures, including strategic management, entrepreneurship, and human resource management.

The theory was developed in 1930's and 1940's in the field of evolutionary biology to explain sexual selection where by traits are selected via the pressure of mate selection. Spence (2002) applied to behavioral finance in 1973 and defined signaling as the idea that one party (termed the agent) conveys some information about itself to another party (the principal). He developed a job market signaling model, where by acquiring certain educational qualifications, potential employees send a signal about their ability level to the employer. These qualifications are assumed to be positively correlated to the job requirements. Signaling theory is fundamentally concerned with reducing information asymmetry between two parties (Spence, 2002). Bird and Smith (2005) postulated that signaling theory is applied to selection scenarios that occur in a range of disciplines from anthropology to zoology. They developed the concept of signal cost through the theory of costly signaling where signalers and receivers have partially conflicting interests such that successful deceit would benefit the signaler at the expense of the receiver. Zhang and Wiersema (2009) posited the example of how CEOs signal the unobservable quality of their firms' potential investors through observable quality of their financial statements. Kirmani and Rao (2000) provided a general example that helps illustrate a basic signaling model where they distinguished between two entities: high quality firms and low-quality firms whereby even though the firms knew their own true quality, outsiders (e.g., investors, customers) do not, so information asymmetry is present. Durcikova and Gray (2009) advanced the signaling theory to signal honesty which is the extent to which the signaller actually has the underlying quality associated with the signal.

In relation to IPO, the signaling theory was first originated by Ibbotson (1975) as a model of underpricing. This theory was refined by (Allen \& Faulhaber, 1989) and (Welch, 1989). Ibbotson (1975) brought in the concept of pricing intended to "leave a good taste in investors mouths", so that issuers can raise equity at higher share prices in the seasoned or subsequent issue. Allen and Faulhaber (1989) demonstrated that the firm has the best information on its present value, risk and its future value than investors. When going public, good firms want to signal their good quality with a low IPO price bringing about "money burning" signal while the bad firms imitate the good firms by signaling that they are good while essentially they are bad.

Under this explanation, high quality firms seek to differentiate themselves by underpricing their IPO. Since high quality firms will have the best performance in the long run, signaling predicts a positive relationship between underpricing and the long term performance. In his seminal paper on uncertainty, Miller (1977) proposed that underpricing arise from the high divergence of opinions in 
IPOs at the time of issue. As time passed, the level of divergence in a stock falls, the average valuation will decrease which results in the steady decrease in share price and thus results in the poor long run performance of IPOs.

The cost of signaling quality is recovered by good firms in subsequent offering and bad firms cannot afford to signal. Welch (1989) indicated that "good" firms will separate themselves from the "bad" firms so as to be able to recoup the losses after their IPO performance. The inability of bad firms to raise resources to meet the initial losses from IPO underpricing causes the separation. The benefit to the bad firm is lost and the cost is higher through a higher level of underpricing which requires more resources in order to imitate the good firm. Welch (1989) established that the issuing prices at the first seasoned equity offering after an IPO are on average three times higher than the IPO prices. This confirms strive to recover the losses of underpriced IPO as a signal for quality of the firm. The model provides an explanation for the IPO pricing as an equilibrium signal of firms' quality (Allen \& Faulhaber, 1989). The IPO underpricing is a signal for preparation for larger more successful subsequent issues. The firm specific factors dictate whether a certain firm can be categorized as good or bad and this is where this theory becomes relevant in this study.

Positive signals and their relevance to the performance of IPO and firm characteristics were discussed by first Welch (1989), Allen \& Faulhaber (1989), and Chemmanur (1993) model that only good firms can afford to dissipate wealth by underpricing. Secondly, Courteau (1995) and Brau, Lambson and McQueen (2005) model that insiders who commit to a long lockup-a period of time after the IPO in which insiders agree not to sell personal shares-signal firm quality thus affecting firm ownership. Thirdly, Teoh, Welch and Wong (1998) suggest that a history of strong earnings signals future strong performance.

\subsection{Agency Theory}

Agency theory is concerned with resolving two problems that can occur in agency relationships. The first arises when the desires or goals of the principal and agent conflict and it is difficult or expensive for the principal to verify what the agent is actually doing. The problem is that the principal cannot verify that the agent has behaved appropriately. The second is the problem of risk sharing that arises when the principal and agent have different attitudes toward risk. Here the principal and the agent may prefer different actions because of the different risk preferences. Because the unit of analysis is the contract governing the relationship between the principal and the agent, the focus of the theory is on determining the most efficient contract governing the principal-agent relationship. The agency structure is applicable in a variety of settings from macro level issues such as regulatory policy to micro level such as blame, impression management, lying, and other expressions of self-interest. Most frequently, agency theory has been applied to organizational phenomena.

Agency theory dates back in 1960s and early 1970s when economists explored 
risk sharing among individuals or groups (Arrow, 1971 and Wilson, 1968). This literature described the risk-sharing problem as one that arises when cooperating parties have different attitudes toward risk. Agency theory broadened this risk-sharing literature to include the $\mathrm{d}$ agency problem that occurs when cooperating parties have different goals and division of labor (Jensen \& Meckling, 1976). Agency theory is directed at the ubiquitous agency relationship, in which one party (the principal) delegates work to another (the agent). It attempts to describe this relationship using the metaphor of a contract. The conflict of interest and agency cost arises due to the separation of ownership from control, different risk preferences, information asymmetry and moral hazards Panda \& Leepsa (2017).

In developing the agency theory, three articles have been influential: Jensen and Meckling (1976) explored the ownership structure of the corporation, including how equity ownership by managers aligns managers' interests with those of owners; Fama (1980) discussed the role of efficient capital and labor markets as information mechanisms that are used to control the self-serving behavior of top executives and combined Fama and Jensen (1983) described the role of the board of directors as an information system that the stockholders within large corporations could use to monitor the opportunism of top executives. It is this third article that is particularly relevant in this study. Lambert (2001) advanced more complicated agency models with multiple principals and agents. In these models, some agents can even be both a principal and an agent. For example, in a hierarchical firm a middle level manager might be an agent of managers above him and a principal of fellow employees below him.

Pepper and Gore (2012) advanced on the traditional agency theory to behavioral agency theory where the interests of shareholders and their agents are most likely to be aligned if executives are motivated to perform to the best of their abilities. They developed a line of argument first advanced by (Wiseman \& Gomez-Mejia, 1998), and put the case for a more general reassessment of the behavioral assumptions underpinning agency theory.

Recent studies have criticized the agency theory. For example, Frydman and Jenter (2010) argued, based on a review of US executive compensation data covering the period 1936 to 2005, that neither optimal contracting (agency theory) nor the managerial power hypothesis is fully consistent with the available evidence. Roberts (2010) on the other hand has commented that agency theory performed poorly during the financial crisis and has reported various situations where strong incentives are evidently not optimal, as agency theory implies.

The relevance of agency theory arises from the fact that boards can be used as monitoring devices for shareholder interests (Fama \& Jensen, 1983). When boards provide relevant and richer information, compensation is less likely to be based on firm performance thus since the behaviors of top executives are better known, compensation based on knowledge of executive behaviors is more likely whereby they are rewarded for taking well-conceived actions whose outcomes 
may be unsuccessful. Also, when boards provide richer information, top executives are more likely to engage in behaviors that are consistent with stockholders' interests. This can be demonstrated by frequency of board meetings, number of board subcommittees, number of board members with long tenure, number of board members with managerial and industry experience, and number of board members representing specific ownership groups. Improved firm performance implies lesser IPO under performance.

In respect to underpricing of IPOs Ritter and Welch (2002) argued that agency conflicts should be addressed in relation to the underpricing of IPOs in future explanations. This conflict of underpricing was first addressed by Baron (1982) making the hypothesis to be known as Baron (1982)'s hypothesis. Accordingly, the issuer is less informed than its underwriter making the issuer to be unable to monitor the underwriter's activity without incurring costs. Muscarella and Vetsuypens (1989) on the other hand found that, when underwriters themselves go public, their shares are also underpriced, even though there is no monitoring problem.

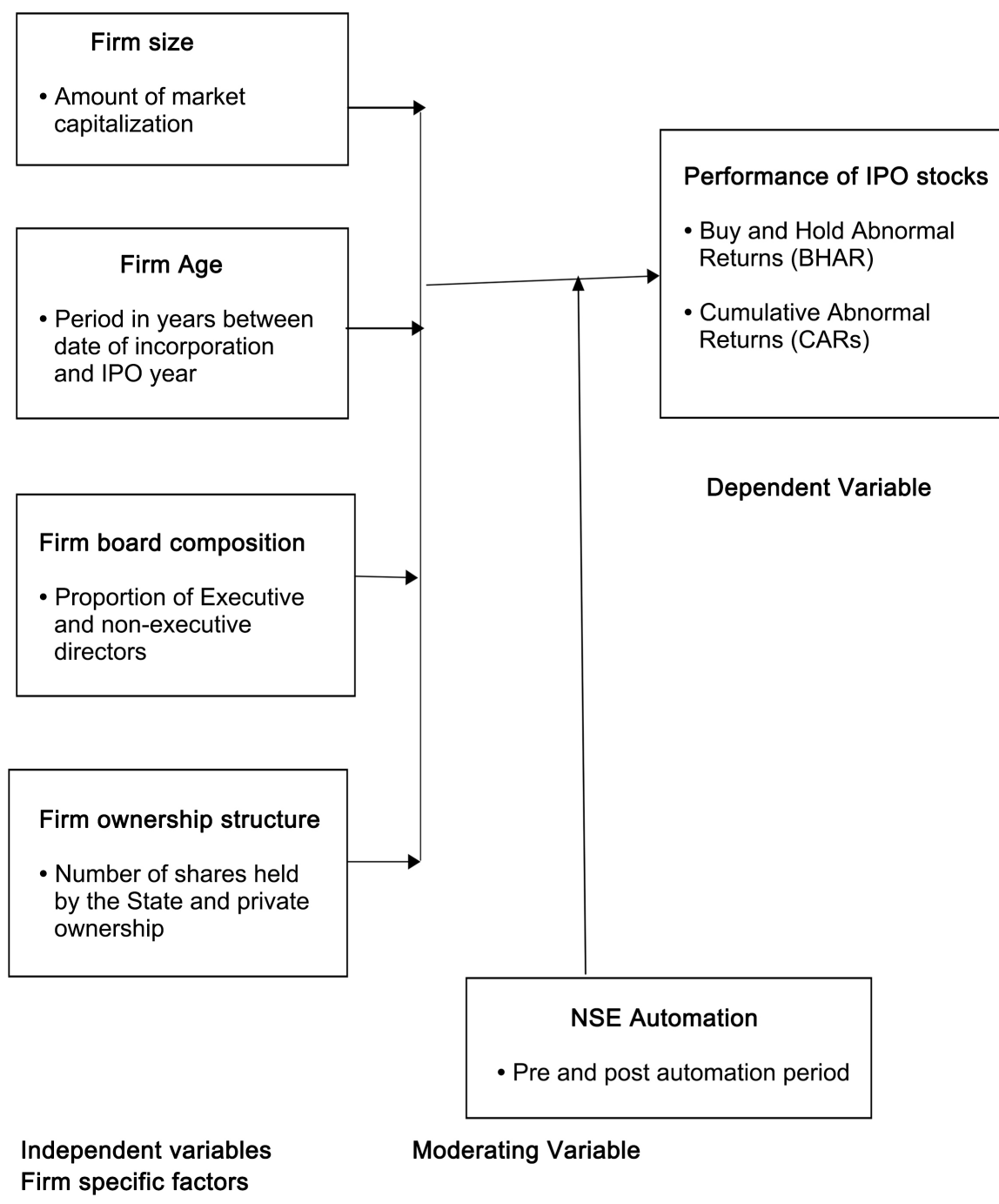




\section{Conceptual Framework}

A concept is an abstract or general idea derived from specific instances (Kombo \& Tromp, 2009). Conceptual framework is a set of ideas and principles from various areas of study used to structure a subsequent presentation. This is achieved through: describing existing practice, projecting future practice and defining terms and salient issues. There are normally two to three variables shown in the conceptual framework: the dependent variable or criterion also called predictor which the researcher wishes to explain, independent variable also known as the explanatory variable which is presumed to be the cause of the changes of the dependent variable (Kothari, 2004).

Conceptual framework's goal is to categorize and describe concepts relevant to a study and map relationships among them. This helps researchers in defining the concepts, identify relationships between various concepts, identify gaps in literature and establish the conceptual scope (Creswell, 2003). The above figure is the conceptual framework for this study.

\section{Conclusion}

This paper has discussed various theories relevant to the IPO stock performance by describing the theory, the proponents of the theory, when the theory was documented or advanced and other authors who used the theory. The theories are hinged to overall IPO performance and firm specific factors as discussed in the research objectives. Different theories can be applied depending on the firm specific factors chosen for study.

\section{Conflicts of Interest}

The authors declare no conflicts of interest regarding the publication of this paper.

\section{References}

Achua, K. (2011). The Dynamics of Initial Price Offerings in Deregulated Emerging African Capital Markets. African Journal of Accounting Economics Finance and Banking Research, 7, 14-35.

Africa Capital Markets Watch (2019). www.pwc.co.za/capitalmarketswatch

Agarwal, S., Liu, C., \& Rhee, S. G. (2008). Investor Demand for IPOs and Aftermarket Performance: Evidence from the Hong Kong Stock Market. Journal of International Financial Markets, Institutions and Money, 18, 176-190. https://doi.org/10.1016/j.intfin.2006.09.001

Allen, F., \& Faulhaber, G. (1989). Signaling by Underpricing in the IPO Market. Journal of Financial Economics, 23, 303-324. https://doi.org/10.1016/0304-405X(89)90060-3

Alvarez, S., \& Gonzalez, V. M. (2001). Long-Run Performance of Initial Public Offerings (IPOs) in the Spanish Capital Market. Journal of Financial Economics, 38, 5-18. https://doi.org/10.2139/ssrn.274086

Arrow, K. (1971). Essays in the Theory of Risk Bearing. Chicago, IL: Markham. 
Barber, M., \& Lyon, D. (1997). Detecting Long-Run Abnormal Stock Returns: The Empirical Power and Specification of Test Statistics. Journal of Financial Economics, 43, 341-372. https://doi.org/10.1016/S0304-405X(96)00890-2

Baron, D. (1982). A Model of the Demand for Investment Banking Advising and Distribution Services for New Issues. The Journal of Finance, 37, 955-976.

Bazerman, M., \& Samuelson, W. (1983). I Won the Auction But Don't Want the Prize. Journal of Conflict Resolution, 27, 618-634. https://doi.org/10.1177/0022002783027004003

Beatty, P., \& Ritter, J. R. (1986). Investment Banking Reputation and Underpricing of Initial Public Offerings. Journal of Financial Economics, 15, 213-232.

Bereby-Meyer, Y., \& Grosskopf, B. (2008). Overcoming the Winner's Curse: An Adaptive Learning Perspective. Journal of Behavioral Decision Making, 21, 15-27.

https://doi.org/10.1002/bdm.566

Bird, R. B., \& Smith, E. A. (2005). Signaling Theory, Strategic Interaction, and Symbolic Capital. Current Anthropology, 46, 221-248. https://doi.org/10.1086/427115

Bodie, Z., Kane, A., \& Marcus, J. (2009). Investment (8th ed.). New York, NY: McGraw Hill.

Bouman, S., \& Jacobsen, B. (2002). The Halloween Indicator, "Sell in May and Go Away": Another Puzzle. American Economic Review, 92, 1618-1635. https://doi.org/10.1257/000282802762024683

Brau, J., Lambson, V., \& McQueen, G. (2005). Lockups Revisited. Journal of Financial and Quantitative Analysis, 40, 519-530. https://doi.org/10.1017/S002210900000185X

Brealey, R. A., Myers, S. C., \& Allen, F. (2005). Corporate Finance (8th ed.). New York, NY: McGraw-Hill Irwin.

Brigham, E. F., \& Ehrhart, M. C. (2011). Financial Management: Theory and Practice (13th ed.). Mason, OH: South-Western Cengage Learning.

Capital Markets Authority, CMA (2020). Capital Markets Authority, Kenya. Quarterly Bulletin.

Chemmanur, T. J. (1993). The Pricing of Initial Public Offers: A Dynamic Model with Information Production. Journal of Finance, 48, 285-304.

https://doi.org/10.1111/j.1540-6261.1993.tb04710.x

Chhabra, K. (2011). Pricing Performance of IPOs in India. Unpublished Thesis, Patiala: Punjabi University.

Chibeka, D. (2014). Effect of Initial Public Offering Pricing on Long Run Stock Returns of Companies Listed at NSE. Unpublished Master of Science Thesis. Nairobi: University of Nairobi.

Courteau, L. (1995). Under-Diversification and Retention Commitments in IPOs. Journal of Financial and Quantitative Analysis, 30, 487-517. https://doi.org/10.2307/2331274

Cox, J. C., \& Isaac, R. (1984). In Search of the Winner's Curse. Economic Inquiry, 22, 579-592. https://doi.org/10.1111/j.1465-7295.1984.tb00705.x

Creswell, J. (2003). Research Design: Qualitative, Quantitative and Mixed Methods Approaches (2nd ed.). Thousand Oaks, CA: SAGE Publications.

Cuthbertson, K., \& Nitzche, D. (2004). Quantitative Financial Economics (2nd ed.). Chichester: John Wiley and Sons.

Dharan, B. G., \& Ikenberry, D. L. (1995). The Long-Run Negative Drift of Post-Listing 
Stock Returns. The Journal of Finance, 50, 1547-1574. https://doi.org/10.1111/j.1540-6261.1995.tb05188.x

Durcikova, A., \& Gray, P. (2009). How Knowledge Validation Processes Affect Knowledge Contribution. Journal of Management Information Systems, 25, 81-108. https://doi.org/10.2753/MIS0742-1222250403

Elton, E. J., Gruber, M. J., Brown, S. J., \& Goetzmann, W. N. (2002). Modern Portfolio Theory and Investment Analysis. New York, NY: John Wiley and Sons.

Ernst and Young Global IPO Trends (2015) 2015 Quarter Two.

Esumanba, S., Kpanie, A., \& Bawuah, B. (2015). Firm Specific Determinants of Underpricing on the Ghana Stock Market. International Review of Management and Business Research, 4, 336-342.

Eyster, E., \& Rabin, M. (2005). Cursed Equilibrium. Econometrica, 73, 1623-1672.

Fama, E. F. (1965). The Behavior of Stock Market Prices. The Journal of Business, 38, 34-105. https://doi.org/10.1086/294743

Fama, E. F. (1980). Agency Problems and the Theory of the Firm. Journal of Political Economy, 88, 288-307. https://doi.org/10.1086/260866

Fama, E. F. (1998). Market Efficiency, Long-Term Returns, and Behavioral Finance. Journal of Financial Economics, 49, 283-306. https://doi.org/10.1016/S0304-405X(98)00026-9

Fama, E. F., \& Jensen, M. C. (1983). Separation of Ownership and Control. Journal of Law and Economics, 26, 301-325. https://doi.org/10.1086/467037

Fawaz, A. S., \& Osama, A. T. (2015). Firm Characteristics and Long Run Abnormal Returns after IPOs: A Jordanian Financial Market Experience. International journal of Economics and Finance, 7, 109-122. https://doi.org/10.5539/ijef.v7n3p109

Frydman, C., \& Jenter, D. (2010). CEO Compensation. Annual Review of Financial Economics, 2, 75-102. https://doi.org/10.1146/annurev-financial-120209-133958

Gasbarro, D., Bundoo, S., \& Zumwalt, J. K. (2003). Underpricing and Aftermarket Performance of IPO Firms in Mauritius. Journal of Emerging Market Finance, 2, 315-335. https://doi.org/10.1177/097265270300200303

Gatumo, M. (2017). What Influences Short Run Performance of Initial Public Offerings in Kenya. Journal of Business and Management, 19, 29-31.

https://doi.org/10.9790/487X-1905062931

Gompers, P. A., \& Lerner, J. (2003). The Really Long-Run Performance of Initial Public Offerings: The Pre-NASDAQ Evidence. The Journal of Finance, 58, 1355-1392. https://doi.org/10.1111/1540-6261.00570

Government of Kenya (2002). Legal Notice No. 60. Nairobi: Government of Kenya.

Hearn, B. (2011). The Impact Of Corporate Governance Measures On The Performance Of West African IPO Firms. Emerging Markets Review, 12, 130-151. https://doi.org/10.1016/j.ememar.2011.02.004

Hirshleifer, D. (2001). Investor Psychology and Asset Pricing. Journal of Finance, 56, 1533-1597. https://doi.org/10.1111/0022-1082.00379

Ibbotson, R. G. (1975). Price Performance of Common Stock New Issues. Journal of Financial Economics, 2, 232-272. https://doi.org/10.1016/0304-405X(75)90015-X

Isnurhadi, S. A. K., Umar, H., Diah, N., \& Herianto, P. (2008). The Analysis of Short Run and Long Run Performance of Privatization Initial Public Offerings in Malaysia. In 8 th Global Conference on Business and Economics (pp. 1-38). Florence: University of Florence. 
Jensen, M., \& Meckling, W. (1976). Theory of the Firm: Managerial Behavior, Agency Costs, and Ownership Structure. Journal of Financial Economics, 3, 305-360. https://doi.org/10.1016/0304-405X(76)90026-X

Joshi, Y., Sabhaya, R., \& Pandya, H. (2013). Are IPOs Underpriced? Empirical Evidence from India. Pacific Business Review International, 6, 80-89.

Kanja, J. (2014). Effect of Initial Public Offerings on the Stock Returns of Companies Listed at the NSE. Unpublished MSc Finance Project, Nairobi: University of Nairobi.

Karanovic, G., \& Karanovic, B. (2016). IPOs Performance Analysis: Evidence from Emerging Markets in the Balkans. Scientific Annals of Economics and Business, 63, 381-389. http://dx.doi.org/10.1515/saeb-2016-0129

Kendall, M. G. (1953). The Analysis of Economic Time Series: Part I: Prices. Journal of Royal Statistical Association, 116, 11-34. https://doi.org/10.2307/2980947

Kiluku, L. (2014). The Relationship between Initial Public Offer Price and the Post Listing Market Price at the NSE for Listed State Owned Enterprises. Unpublished these of Master of Science in Finance, Nairobi: University of Nairobi.

Kinyua, J., Nyanumba, P., Gathaiya, R., \& Kithitu, J. (2014). Effects of IPO on Performance of Companies Quoted at NSE. International Journal of Management and business Studies, 3, 81-84.

Kirmani, A., \& Rao, A. R. (2000). No Pain, No Gain: A Critical Review of the Literature on Signaling Unobservable Product Quality. Journal of Marketing, 64, 66-79.

https://doi.org/10.1509/jmkg.64.2.66.18000

Koech, C. (2011). Short-Run and Long-Run IPO Financial Performance for Firms Quoted at the Nairobi Stock Exchange. Unpublished Master of Business Administration Thesis, Nairobi: University of Nairobi.

Kombo, D. K., \& Tromp, D. L. A. (2009). Proposal and Thesis Writing: An Introduction. Nairobi: Pauline's Publications Africa.

Kooli, M., \& Suret, J. (2004). The Aftermarket Performance of Initial Public Offerings in Canada. Journal of Multinational Financial Management, 14, 47-66. https://doi.org/10.1016/S1042-444X(03)00038-0

Kothari, C. (2004). Research Methodology: Methods \& Techniques (2nd ed.). New Delhi: New Age International Publishers.

Kothari, S., \& Warner, J. B. (1997). Measuring Long-Horizon Security Price Performance. Journal of Financial Economics, 43, 301-339. https://doi.org/10.1016/S0304-405X(96)00899-9

Lagoarde-Segot, T., \& Lucey, B. M. (2008). Efficiency in Emerging Markets-Evidence from The MENA Region. Journal of International Financial Markets, Institutions and Money, 18, 94-105. https://doi.org/10.1016/j.intfin.2006.06.003

Lambert, R. A. (2001). Contracting Theory and Accounting. Working Paper, Philadelphia, PA: University of Pennsylvania. https://doi.org/10.2139/ssrn.235800

Lee, P. J., Taylor, S. L., \& Walter, T. S. (1996). Australian IPO Pricing in the Short and Long Run. Journal of Banking and Finance, 20, 1189-1210. https://doi.org/10.1016/0378-4266(95)00053-4

LeRoy, S. F. (1989). Efficient Capital Markets and Martingales. Journal of Economic Literature, $27,1583-1621$.

Levis, M., (1993). The Long-Run Performance of Initial Public Offerings: The UK Experience 1980-1988. Financial Management, 22.

Ljungqvist, A. P. (1997). Pricing Initial Public Offerings: Further Evidence from Germa- 
ny. European Economic Review, 41, 1309-1320.

https://doi.org/10.1016/S0014-2921(96)00035-9

Lo, A. W., \& MacKinley, A. C. (1999). A Non-Random Walk Down Wall Street. Princeton, NJ: Princeton University Press.

Loughran, T., \& Ritter, J. R. (1995). The New Issues Puzzle. The Journal of Finance, 50, 23-51. https://doi.org/10.1111/j.1540-6261.1995.tb05166.x

Loughran, T., \& Ritter, J. R. (2002). Why Don't Issuers Get Upset about Leaving Money on the Table in IPOs? Review of Financial Studies, 15, 413-444. https://doi.org/10.1093/rfs/15.2.413

Loughran, T., Ritter, J., \& Rydqvist (2020). Initial Public Offerings-International Insights. Pacific-Basin Finance Journal, 2, 165-199.

Lyon, J., Barber, B., \& Tsai, C. (1999). Improved Methods for Tests of Long-Run Abnormal Stock Returns. Journal of Finance, 54, 165-201. https://doi.org/10.1111/0022-1082.00101

Madura, J. (2010). Financial Institutions and Markets (10th ed.). Mason, OH: Thomson South-Western.

Marc, G., Khurshed, A., \& Mudambi, R. (2006). The Strategy of Going Public: How UK Companies Choose Their Listing Contracts. Journal of Business Finance and Accounting, 33, 79-101. https://doi.org/10.1111/j.1468-5957.2006.00657.x

Marc, G., Khurshed, A., \& Mudambi, R. (2007). The Long-Run Performance of UK IPOs: Can It Be Predicted? Managerial Finance, 33, 401-419. https://doi.org/10.1108/03074350710748759

Mburugu, S. (2016). Analysis of the Long Run Performance of Initial Public Offers and Effects in the Kenyan Stock Market. Unpublished Master of Science Project, Nairobi: University of Nairobi.

Miller, E. M. (1977). Risk, Uncertainty, and Divergence of Opinion. Journal of Finance, 32, 1151-1168. https://doi.org/10.1111/j.1540-6261.1977.tb03317.x

Miller, R. E., \& Reilly, F. K. (1987). An Examination of Mispricing, Returns and Uncertainty for Initial Public Offerings. Financial Management, 16, 33-38.

https://doi.org/10.2307/3666001

Mitchell, M., \& Stafford, E. (2000). Managerial Decisions and Long-Term Stock Price Performance. The Journal of Business, 73, 287-329. https://doi.org/10.1086/209645

Munisi, H. (2017). Financial Performance of Initial Public Offerings: Companies listed on Dar es Salaam Stock Exchange. Business and Economics Journal, 8, Article No. 302.

Muscarella, C. J., \& Vetsuypens, M R. (1989). A Simple Test of Baron's Model of IPO Underpricing. Journal of Financial Economics, 24, 125-135.

https://doi.org/10.1016/0304-405X(89)90074-3

Mushtag, K. (2016). Factors That Influence the Performance of IPO at the NSE in Kenya. Unpublished MBA Thesis, Nairobi: University of Nairobi.

Mutai, J. (2018). Effects of Firm Characteristics on the Post-IPO Performance by Listed Companies on the Nairobi Securities Exchange (NSE), Kenya. African Journal of Education, Science and Technology, 5, 160-170.

Mutai, J. (2019). Effects of IPO Timing on the Underpricing of Shares of Companies Listed on Nairobi Securities Exchange (NSE), Kenya. African Journal of Education, Science and Technology, 5, 111-121.

Mwendwa, M. (2014). Effects of IPO on Long Run Stock Price Performance of Companies Listed at the NSE. Unpublished Project. Nairobi: University of Nairobi 
Neneh, B. (2013). Returns on Initial Public Offerings (IPOs) on the Johannesburg Securities Exchange (JSE): Success and Failure Patterns. Unpublished Thesis. Bloemfontein: University of the Free State.

Ng'ang'a, P. (2017). Effect of Ownership Structure on Financial of Companies Listed at the Nairobi Securities Exchange in Kenya. Unpublished Ph.D. in Business Administration (Finance), Kenya: Jomo Kenyatta University of Agriculture and Technology.

Obura, J., \& Anyango, C. (2016). Moderating Effect of Interest Rates on relationship between Foreign Exchange Rate Fluctuation and Performance of Nairobi Securities Exchange Market. Universal Journal of Accounting and Finance, 4, 27-34. https://doi.org/10.13189/ujaf.2016.040201

Omuchesi, J., \& Bosire, M. (2014). The Effect of Automation on Stock Market Efficiency: A Case of Nairobi Securities Exchange. A Research Journal of Finance and Accounting, 5, 71-79. https://doi.org/10.9790/5933-0537179

Osei, K. A., Adjasi, C. K., \& Fiawoyife, E. U. (2012). Underpricing of Initial Public Offerings on Africa Stock Markets: Ghana and Nigeria. Nairobi: The Africa Economic Research Consortium.

Panda, B., \& Leepsa, N. (2017). Agency Theory: Review of Theory and Evidence on Problems and Perspectives. Indian Journal of Corporate Governance, 10, 74-95. https://doi.org/10.1177/0974686217701467

Pepper, A., \& Gore, J. (2012). Behavioral Agency Theory: New Foundations for Theorizing about Executive Compensation. London School of Economics and Political Science Research, 41, 1045-1068. https://doi.org/10.1177/0149206312461054

Philippe, E. (2012). IPO: A Global Guide (Expanded 2nd ed.). Hong Kong: Hong Kong University Press.

Ritter, J. (1998). Initial Public Offerings. Warren Gorham and Lamont Handbook of Modern Finance, 2, 5-30.

Ritter, J. (2011). Equilibrium in IPO Market. Annual Review of Financial Economics, 3, 347-374. https://doi.org/10.1146/annurev-financial-102710-144845

Ritter, J., and Welch, I. (2002). A Review of IPO Activity, Pricing and Allocations. Cambridge, MA: National Bureau of Economic Research. https://doi.org/10.3386/w8805

Roberts, J. (2010). Designing Incentives in Organizations. Journal of Institutional Economics, 6, 125-132. https://doi.org/10.1017/S1744137409990221

Rock, K. (1986). Why New Issues Are Underpriced. Journal of Financial Economics, 15, 187-212. https://doi.org/10.1016/0304-405X(86)90054-1

Ross, R. (2012). Off the Rails: Is Dow Theory Still Applicable to Today's Market. Casey Research, 1-3. www.caseyresearch.com/daily-dispatch/rails-dow-theory-still-applicable-todays-market

Sarra, B. S., Abdelkader, B., \& Neila, B. T. (2011). Determinants of IPO Underpricing: Evidence from Tunisia. The International Journal of Business and Finance Research, 5, 13-32.

Simiyu, F., Mutunga, T., Barasa, F., \& Matete, S. (2016). Effects of Initial Public Offerings on Long Run Performance of Stocks Listed on NSE Market. Quest Journals of Research in Business and Management, 4, 43-50.

Spence, M. (2002). Signaling in Retrospect and the Informational Structure of Markets. American Economic Review, 92, 434-459. https://doi.org/10.1257/00028280260136200

Spiess, D. K., \& Affleck. J. (1995). Underperformance in Long-Run Stock Returns Following Seasoned Equity Offerings. Journal of Financial Economics, 38, 243-267. 
https://doi.org/10.1016/0304-405X(94)00817-K

Teoh, S. H., Welch, I., \& Wong, T. J. (1998). Earnings Management and the Long-Run Performance of Initial Public Offerings. Journal of Finance, 53, 1935-1974. https://doi.org/10.1111/0022-1082.00079

Varaiya, P. (1988). The "Winner's Curse" Hypothesis and Corporate Takeovers. Managerial and Decision Economics, 9, 209-219. https://doi.org/10.1002/mde.4090090306

Wamari, E. (2014). The Effect of Initial Public Offers on Long Run Stock Performance: Evidence from the Nairobi Securities Exchange. International Journal of Science and Research Publications, 4, 1-9.

Welch, I. (1989). Seasoned Offerings, Imitation Costs, and the Underpricing of IPOs. Journal of Finance, 44, 421-449. https://doi.org/10.1111/j.1540-6261.1989.tb05064.x

Wilson, R. (1968). On the Theory of Syndicates. Econometrica, 36, 119-132. https://doi.org/10.2307/1909607

Wiseman, R., \& Gomez-Mejia, L. (1998). A Behavioral Agency Model of Managerial Risk Taking. The Academy of Management Review Journal, 23, 133-153. https://doi.org/10.5465/amr.1998.192967

Yaakub, N., Sherif, M., \& Haniffa, R. (2018). The Post-Issue Market Performance of Initial Public Offerings: Empirical Evidence from Malaysian Stock Markets. Journal of Emerging Market Finance, 17, 376s-414s. https://doi.org/10.1177/0972652718798188

Zhang, Y., \& Wiersema, M. F. (2009). Stock Market Reaction to CEO Certification: The Signaling Role of CEO Background. Strategic Management Journal, 30, 693-710. https://doi.org/10.1002/smj.772

Zheng, X. F. S., Ogden, J. P., \& Jen, F. C. (2002). Pursuing Value through Liquidity: Share Retention, Lockup and Underpricing in IPOs. Working Paper. https://doi.org/10.2139/ssrn.338281

Zouari, S., Baldrige, A., \& Taktak, N. (2011). Determinants of IPO Underpricing: Evidence from Tunisia. The International Journal of Business and Finance Research, 5, 13-32. 